\title{
Technologies for Water Reuse: Current Status and Future Challenges
}

\author{
Mauro Capocelli * (D) and Vincenzo Piemonte \\ Faculty of Engineering, University Campus Bio-Medico of Rome, 00128 Rome, Italy; v.piemonte@unicampus.it \\ * Correspondence: m.capocelli@unicampus.it
}

Citation: Capocelli, M.; Piemonte, V. Technologies for Water Reuse:

Current Status and Future Challenges. Water 2021, 13, 832. https://doi.org/ $10.3390 /$ w13060832

Received: 27 January 2021

Accepted: 16 March 2021

Published: 18 March 2021

Publisher's Note: MDPI stays neutral with regard to jurisdictional claims in published maps and institutional affiliations.

Copyright: () 2021 by the authors. Licensee MDPI, Basel, Switzerland. This article is an open access article distributed under the terms and conditions of the Creative Commons Attribution (CC BY) license (https:// creativecommons.org/licenses/by/ $4.0 /)$.
Water is fundamental for the quality of both ecosystems and society, and plays a key role for energy and food production, a prerequisite for the sustainable development. The management of water resources is interconnected with almost all the Sustainable Development Goals because it is at the basis of biodiversity preservation, economy and wellbeing as well as poverty reduction. The themes of climate change and circular economy are strongly interconnected with water, as stated by the new Green Deal of the EU Commission, because of the intrinsic nexus between fundamental resources (water, energy and food) and the habits of the world population that is growing and is moving from farms to cities, pursuing higher and higher living standards [1,2].

Demographic and climate changes produces dramatic effects on the resources: the internal renewable freshwater per capita (long-term average water availability from precipitation, groundwater recharge, and surface inflows) is constantly decreasing; the population living under conditions of "water scarcity" at least one month of the year is around 4 billion and is expected to reach the half of the world population in 2050. The worldwide water requirement has been increasing by more than three times (since 1950) reaching $4000 \mathrm{~km}^{3} / \mathrm{y}$ and is expected to reach the value of $6000 \mathrm{~km}^{3} / \mathrm{y}$ in 2050 .

A huge amount of water is consumed in both the agricultural and industrial sectors with the major percentage devoted to thermal power generation. As example, water consumption in the cooling water cycle of thermoelectric power plants is around $3 \mathrm{~m}^{3} / \mathrm{MWh}$. Just as water is fundamental in the energy sector, any water treatment process requires a lot of energy. As example, conventional treatment of wastewaters requires around $0.5 \mathrm{kWh} / \mathrm{m}^{3}$ and desalination of seawater around $5 \mathrm{kWh} / \mathrm{m}^{3}$ [3].

In the view of climate change mitigation, is worth noticing that water is the key resource in the natural regulation of the carbon cycle since the ocean and the vegetation (photosynthesis process) naturally exchange more than $200 \mathrm{Gt}$ of Carbon per year. On the other hand, the climate crisis challenges the availability of freshwater and increase inequalities on a global scale. Increased surface runoff and evapotranspiration as well as dramatic mutation of the intensity and frequency of precipitations impact water availability of entire countries. Moreover, the negative impacts of climate change will affect the water systems by hitting different features as water quality and temperature as well as water infrastructures.

On the other hand, in any future scenario considering the climate mitigation options, water demand would increase because of the increased need of cooling both in the residential and the industrial world. As an example, the specific water consumption in the energy sector (measured in $\mathrm{m}^{3} / \mathrm{MWh}$ ) will increase if carbon capture and storage (CCS) will be applied; this is due to both the reduced power produced per unit of primary energy and the increased need of water in energy-related processes (e.g., for the intercooled compression and condensation of the captured $\mathrm{CO}_{2}$ ).

These interconnections between water and key factors of our life and our economies highlight the role of water as the symbol of the modern vicious circle that puts the relationship between economy and environment in crisis. According to several scientific and 
economic journals, water is posed to be the oil of this century as clean water demand will exceed the availability in 2050. Without water, everything else in the EUR 69.8 trillion global economy would fail. A total of $75 \%$ of our jobs depend on water and water crises rank among the top 5 global risks in terms of impact; as an example, the World Bank has warned that worsening water scarcity fuelled by climate change could cost regions such as the Middle East and North Africa up to 6 percent of their GDP in the next few decades [1,2].

Meeting the increasing water demand foreshadows a strong increase in "artificial" water obtained from non-conventional sources (as wastewaters or seawater) such as desalination and water reuse technologies. Indeed, wastewater can be considered a "misplaced resource", suitable for the recovery of energy, valuable materials and, obviously, clean water. Although many industries are promoting the zero-liquid discharge (ZLD) approach in different sectors (to reduce both freshwater abstraction and the discharge/environmental impacts), the reuse of treated wastewater is under-exploited [3].

In order to increase water supply and to alleviate the pressure on over-exploited water resources in the context of a circular economy, the applications of treated wastewater could be various: irrigation (both agricultural and landscape), recharge of aquifers, seawater barriers, industrial cooling, dual-distribution systems for toilet flushing, and other urban uses. Pioneers in this field are Israel, where more than the $80 \%$ of treated wastewaters is reused (mainly for agricultural irrigation) and Singapore where up to 30\% of the nation's current water needs is met with water reuse.

Despite a few virtuous examples, the EU water systems (with its infrastructures and processes) is ineffective from the point of view of the "circularity of resources" and very energy- and water-intensive. Today, less than the 3\% of the EU urban wastewater effluents is reused and less than $1 \%$ of annual freshwater withdrawals is reused annually [1,2]. From the industrial side, the water system is still "open": it starts with the withdrawal of freshwater and finishes with the discharge of degraded forms of waters from the point of view of both temperature and composition.

Some papers of this research group promoted the "closed-cycle approach" (in a basin or similar delimited region) to realize virtuous strategies capable to keep the aquifer at a constant level by introducing water from non-conventional sources [3]. These additional streams of water can be obtained by virtuous processes such as desalination of seawater (or brackish water) or water-reuse processes and can be suitable for different uses (of different quality standards) [3]. Moreover, these projects should be rewarded by the community because they save "renewable water". In our papers, we proposed an economic incentive to reward these water treatment and reuse projects based on the actual value of water. This "value" was set on thermodynamic basis by relating water quality to the work required for treatment/purification (e.g., seawater desalination). A future "virtuous territory" must include "holistic Wastewater Treatment Plants (WWTPs)" as the centres to recovery water at different quality (from washing purposes to potabilization) as well as resources and energy. Most of the innovative "holistic approaches" include biological degradation (e.g., anaerobic digestion) also integrated with other sources of organic waste. A key waste stream in these biological processes are biosolids, which can then be treated by thermoconversion processes such as incineration, gasification, hydrothermal carbonization. Many schemes are discussed in the literature; an extensive review with possible material and energy balances around modern WWTPs is given by Scherson and Criddle [4]. On the other hand, the concept of recovery valuable resource from non-conventional waters has been deeply discussed by Puyol et al [5] for wastewaters in general and by Drioli et al (for the particular case of seawater) [6].

This Special Issue is devoted to a deeper analysis of current and future technologies for water treatment with particular focus on the barriers and the opportunities. A total of eight selected articles cover three hot topics in the water-technology panorama. Some papers are devoted to the analysis of state of the art and barriers (e.g., public acceptance) in the cited fields, also by carrying out meta-analysis $[7,8]$ and by focusing on water quality $[9,10]$. A total of three published papers deal with innovative processes to remove 
organic micropollutant by means of biological treatment, adsorption or advanced oxidation processes [11-13]. Two papers focus on the removal of ions from water $[10,14]$ with a particular focus on the energy recovery from wasted stream given in the final work of Capocelli et al. [14].

Although not exhaustive, the topics covered by the Special Issue can give the picture of how multidisciplinary the research in this sector is and how it is necessary to integrate different aspects of knowledge to optimize and to adopt virtuous and efficient reuse systems. To increase the percentage of water recovery in our systems, many progresses in both water treatment and water management are needed, with a particular attention to the water-energy nexus to exploit synergies between these two strongly interconnected worlds.

Author Contributions: The two authors made equal contributions to this editorial. All authors have read and agreed to the published version of the manuscript.

Funding: This research received no external funding.

Institutional Review Board Statement: Not applicable.

Informed Consent Statement: Not applicable.

Data Availability Statement: Not applicable.

Acknowledgments: The authors appreciate the efforts of the Water editors and publication team at MDPI and the anonymous reviewers for their invaluable comments.

Conflicts of Interest: The authors declare no conflict of interest.

\section{References}

1. Position Paper on Water, Energy, Food and Ecosystems (WEFE) Nexus and Sustainable Development Goals (SDGs), EUR 29509 EN; Publications Office of the European Union: Luxembourg, 2018. Available online: https:/ /op.europa.eu/en/publication-detail/-/ publication/265bda85-88db-11e9-9369-01aa75ed71a1/language-en (accessed on 14 January 2020).

2. Water Europe. Contributions to the European Green Deal and Horizon Europe: Water Europe Vision Implementation-Annexes; Water Europe: Brussels, Belgium, 2020, ISBN 9789464003079.

3. Capocelli, M.; Prisciandaro, M.; Piemonte, V.; Barba, D. A technical-economical approach to promote the water treatment \& reuse processes. J. Clean. Prod. 2019, 207, 85-96. [CrossRef]

4. Scherson, Y.D.; Criddle, C.S. Recovery of Freshwater from Wastewater: Upgrading Process Configurations to Maximize Energy Recovery and Minimize Residuals. Environ. Sci. Technol. 2014, 48, 8420-8432. [CrossRef] [PubMed]

5. Puyol, D.; Batstone, D.J.; Hülsen, T.; Astals, S.; Peces, M.; Krömer, J.O. Resource Recovery from Wastewater by Biological Technologies: Opportunities, Challenges, and Prospects. Front. Microbiol. 2017, 7, 2106. [CrossRef] [PubMed]

6. Drioli, E.; Ali, A.; Macedonio, F.; Quist-Jensen, C.A. Minerals, Energy and Water from the Sea: A New Strategy for Zero Liquid Discharge in Desalination. JSM Environ. Sci. Ecol. 2015, 3, 1018.

7. Li, L.; Duan, M.; Fu, H. Supporter Profiling in Recycled Water Reuse: Evidence from Meta-Analysis. Water 2020, $12,2735$. [CrossRef]

8. Betanzo-Torres, E.A.; Piñar-Álvarez, M.D.L.Á.; Sandoval-Herazo, L.C.; Molina-Navarro, A.; Rodríguez-Montoro, I.; González-Moreno, R.H. Factors That Limit the Adoption of Biofloc Technology in Aquaculture Production in Mexico. Water 2020, 12, 2775. [CrossRef]

9. Kim, D.-H.; Choi, C.; Lee, C.; Adha, R.S.; Nguyen, T.-T.; Ahn, S.-J.; Son, H.-J.; Kim, I.S. An Improved Configuration of Vertical-Flow Mesh Tube Filters for Seawater Pretreatment: Performance, Cleaning, and Energy Consumption. Water 2020, 12, 2804. [CrossRef]

10. Prisciandaro, M.; Innocenzi, V.; Tortora, F.; di Celso, G.M. Reduction of Fouling and Scaling by Calcium Ions on an UF Membrane Surface for an Enhanced Water Pre-Treatment. Water 2019, 11, 984. [CrossRef]

11. Di Palma, L.; Bavasso, I.; Capocelli, M.; de Filippis, P.; Piemonte, V. Biological Treatment of Wastewater from Pyrolysis Plant: Effect of Organics Concentration, $\mathrm{pH}$ and Temperature. Water 2019, 11, 336. [CrossRef]

12. Mazzeo, L.; Bavasso, I.; Bracciale, M.P.; Cocchi, M.; di Palma, L.; Piemonte, V. Yerba Mate (Ilex paraguarensis) as Bio-Adsorbent for the Removal of Methylene Blue, Remazol Brilliant Blue and Chromium Hexavalent: Thermodynamic and Kinetic Studies. Water 2020, 12, 2016. [CrossRef]

13. Capocelli, M.; de Crescenzo, C.; Karatza, D.; Lancia, A.; Musmarra, D.; Piemonte, V.; Prisciandaro, M. A Transport-Phenomena Approach to Model Hydrodynamic Cavitation of Organic Pollutants. Water 2020, 12, 1564. [CrossRef]

14. Capocelli, M.; Moliterni, E.; Piemonte, V.; de Falco, M. Reuse of Waste Geothermal Brine: Process, Thermodynamic and Economic Analysis. Water 2020, 12, 316. [CrossRef] 